\author{
Grzegorz Godlewski \\ https:/ /orcid.org/0000-0002-5860-1795 \\ Adam Mickiewicz University in Poznań \\ Faculty of Geographical and Geological Sciences \\ Department of Tourism and Recreation \\ godlewskig@wp.pl
}

\title{
CONTROVERSIAL TYPES OF TRAVEL AND THE POSITION OF POLISH TOURISM SERVICE PROVIDERS: EXPERIENCE TOURISM
}

\begin{abstract}
The aim of this study is to investigate the potential of the Polish market for the development of the supply-side of controversial forms of tourism, based on the opinions and products offered by tour operators and retail travel agents. Analytical data were collected using desk research and CATI $(\mathrm{N}=107)$ methods. The most common controversial types of tourism include drug and sex tourism, followed by disaster tourism, medical tourism, slum tourism, fan tourism and poverty tourism. The expectations of customers regarding tourism offers usually focus on party tourism and extreme travel, and the providers highlight that this market segment will continue to develop.
\end{abstract}

Keywords: travel market controversies, experience tourism.

\section{INTRODUCTION}

The subject discussed in this paper is one the most complex related to the tourism industry. This complexity applies not only to the cognitive issues that stem from data collection procedures used in academic analysis and interpretation, but also to the multiplicity of factors that affect the consumption of tourism products. For obvious reasons, the entirety cannot be exhaustively discussed in a single paper.

The Polish academic community has already attempted to conduct research and prepare publications in the field of controversial tourism. Usually, they cover only a single selected type and seldom discuss the entire category, which after all is necessary to obtain a relatively full picture of the processes which determine the development of a given market sector. The gaps in the existing literature, which prevent an in-depth substantial discussion, demonstrate a vast research potential related to controversial forms of tourism, especially in the context of correlations between tourism phenomena, dysfunctional human behaviour and ethical issues.

The aim is to diagnose the market potential for the development of controversial forms of tourism in Poland based on opinions obtained from service providers: tour operators and retail travel agents.

The detailed objectives were as follows:

1. To identify whether respondents are familiar with the needs of their clients in the context of the fre- quency of their queries regarding controversial tourism offers;

2. To answer the question whether the tourism industry is moving towards treating controversial forms of tourism as an important component.

For the purpose of this study, it was assumed that this segment of the tourism market is strictly connected to the experiences which modern consumers look for in relation to dysfunctional types of travel.

\section{EXPERIENCE IN TOURISM}

The experience economy has its roots in the USA, dates back to the end of the $20^{\text {th }}$ century and depicts the modern consumer as a person whose choices are based on emtions (Kacprzak, Dziewanowska, Skorek, 2015; Stasiak, 2013). In 1992, a German sociologist, Schulze, described the idea of an 'experiencing society' (Erlebnisgesellschaft). The term was taken up by Pine \& Gilmore (1998) and since then has been commonly applied in academic discourse.

The factor that is the basis for creating experiences is the presence of a person (with knowledge, sensitivity) and resources, goods and services. However, it is the experiences that are the precondition for market exchange, as customers making purchase decisions evaluate whether 
consumption will provide them with expected (usually positive) experiences. Culture is also a strong incentive for the development of the experience economy. As it undergoes a 'carnivalisation' process, consumers are overwhelmed by an excess of material goods and look for new stimuli. This creates a self-perpetuating mechanism, making it the task of suppliers to create and provide fun and amusement (Barber, 2008; Bauman, 2007).

The tourism industry is strongly associated with changes occurring in the life of the traveller. Travelling provides new stimuli: new locations, people, products or experiences. Experience in tourism is often based on the authenticity of the offer and the accompanying experience. This concept was first proposed by MacCannell $(1973,1976)$ fifty years ago but there are also more recent publications (e.g. Åstrøm, 2017; Sigala, 2016; Weisheng, Ho, 2017; Zatori, Beardsley, 2017).

Experts admit that tourism is an important part of the industry, selling experiences anchored in human behaviour, which are very personal and subjective (Ooi, 2002; Prentice, Witt, Hamer, 1998). These multifaceted experiences are described in environmental and social contexts (Abrahams, 1986).

Tourist experiences are not reflected in the same way in different societies and their complexity has already been discussed in the subject literature (Lee, Shafer, 2002) and different methods have been developed to distinguish between them. Initially, researchers focused on cognitive psychology (Lee, Shafer, 2002; Stamboulis, Skayannis, 2003) studying the processes of experience perception by tourists (Waitt, 2000; Waller, Lea, 1999). Their imaginations and expectations determine the consumption and evaluation of a tourism product. Authors of other publications claim that tourist activity allows for gathering experiences, especially those that are considered most beneficial for the individual. They include improvement of well-being, providing a chance to express identity and allowing for in-depth contemplation of visited sites and cultures (Lee, Shafer, 2002; Prentice, Witt, Hamer, 1998). The drive towards consumption of tourist experiences becomes a means in reaching this goal (Ooi, 2003).

Empirical, strong sensations, felt in the case of optimum experiences, create a psychological state that is described by tourists as exceptional (Ellis, 1994; Walker, Hull, Roggenbuck, 1998). This type of experience is very engaging, emotionally intense, and sometimes bordering on the transcendent (Csíkszentmihályi, 1993).

Travel experiences may also reveal differences between the inhabitants of the regions visited and tourists. Urry (1990) highlights the fact that while experiencing new locations, tourists notice things which they would not notice in their everyday surroundings. They do not have sufficient knowledge to see reality in the same way native inhabitants do and apply a certain filter to the actual image of a place that is a reflection of their own envi- ronment (Ooi, 2002). Thus, tourists only get to know an approximation of the local culture whose availability to visitors is limited (Hannabuss, 1999; Ooi, 2002).

Extensive travel motivations increasingly often result in new typologies of travel, however their origins seem to correlate with traditions. When analysing the behaviour of rafting trip participants, Arnould \& Price (1993) determined the following dimensions of experience: harmonious closeness to nature, sense of community, personal development and renewal.

When analysing tourism services, researchers developed other, more complex typologies. One such was proposed by Otto \& Ritchie (1996) whose six dimensions, hedonism, interactivity, novelty/originality, comfort, safety and stimulation, provide a powerful compilation of experiences in tourism. It is difficult not to agree with such a claim, as almost every type of travel reflects this diversity, although some elements are more or less accentuated depending on the category of customer and the assumptions of the provider. The set of features listed above has been complemented by Rageh, Melewar \& Woodside (2013) with education, relation-building, admiration and beauty, perfectly fitting in with heritage, adventure and active tourism. This also applies to the experiences related to personal relevance, novelty/originality, surprise, learning, and engagement proposed by Poulsson \& Kale (2004).

Another interesting idea is the theatrical concept, according to which stimuli provided result in specific emotions of the recipients. This concept consists in adapting some elements of a theatrical metaphor to business practice and initiating a project resembling an actual theatrical play. The mechanisms are akin to those involved in art contemplation - products and services are transient in nature (similar to a play) and result in specific emotions present in human relations (also found in the theatre). The scope of application of the theatrical metaphor is very broad as it pertains to retail commerce (Harris, Harris, Baron, 2003; Deighton, 1999; Goodwin, 1996), health care and higher education institutions (John, 1996; Williams, Anderson, 2005).

Research on the travel market through the experience economy includes finding new destinations and creating tourism products. The present paper focuses on tourism with its wide spectrum of forms, especially those which are considered controversial. Their nature, although corresponding to terminological aspects of tourism, creates social doubts considering their economic aspects.

\section{CONTROVERSIAL ASPECTS OF TOURISM}

The Polish lexicographer Kopaliński (2014) defines 'controversy' as a doubt, a quarrel or a dispute, while the PWN Polish Language Dictionary further expands the defi- 
nition, describing it as a difference of opinion resulting in discussions and disputes (Słownik języka polskiego, 2018). Another lexicographer adds that something is controversial when it expresses a negative view on a given subject (Bańko, 2007).

Despite definition-related doubts among tourism industry experts and researchers, it is possible to define controversial tourism as an activity provoking controversies and discussions, often presented in a negative light (Stasiak, 2015). Lubowiecki-Vikuk \& PaczyńskaJedrycka (2010) narrow the term down to activities with clear negative connotations, related to law violation (abortion, euthanasia, drug tourism). The subject literature however presents a broader understanding of controversy in the travel industry (Moufakkir, Burns, 2012).

Stasiak (2015) distinguished five major areas causing disputes and conflicts: tourist behaviour, travel destination, forms of tourism, tourism products and tourism effects. This means that travelling may cause numerous, multifaceted dysfunctions.

It is impossible to directly assign one controversy category to a given form of tourism and tourist behaviour. Usually, similar to tourist functions, the categories are inseparable from one another and every attempt at systematisation is bound to become subject to justified criticism.

The major differentiator in controversial tourism are the motives for participating in it, especially from the perspective of various tourism market segments. Panasiuk (2015) classifies them into potentially controversial, moderately controversial and commonly considered to be controversial. However, the boundaries between individual classes remain very subjective.

The supply structure in the tourism market focused around controversial travel seems to be even more com- plex. First of all, one should consider tourist offers created by entrepreneurs in the tourism industry with the purpose of influencing the motives and behaviour of tourists. When referring to a tourism product, the following controversies may be considered: partial tourism services (e.g. low-quality services), incomplete tourism packages (without compulsory insurance, sold at low prices, offered at an unsuitable time - in an off-season), prices (considerably higher or lower compared to the standard prices offered by competitors) and the quality parameters of the offer (Panasiuk, 2015).

Other controversial aspects may also pertain to tourist resources both natural and cultural: tourist attractions, tourist infrastructure, tourist services, offer comprehensiveness in tourist destinations, marketing activities and tourism image (Panasiuk, 2015).

Finally, it is also worth mentioning economic controversies arising in relation to modern tourism. Examples of such controversies are the economic exploitation of poor countries with weaker economies by the international tourism industry, tourist neo-colonialism expressed through the construction of 'tourist ghettos', and the transfer of almost all profits from investment abroad, resulting in a so-called 'tourist monoculture' through its large scale. Recession (reduction in inbound tourism) may lead to the destabilisation of a host country creating even deeper economic dependence (Jasiński, 2006).

Views on 'who is to blame' for the development of controversial types of tourism vary (Podemski, 2013). In their search, travellers often fall victim to the tourism industry (MacCannell, 2002), yet it is their fault as they have demanded products belonging to this category in the first place.

Table 1. Controversial types of travel

\begin{tabular}{|l|l|}
\hline \multicolumn{1}{|c|}{ Type of tourism } & \multicolumn{1}{c|}{ Controversies } \\
\hline Abortion tourism & Performing abortions without medical indications in countries with liberal legal systems \\
\hline Euthanasia tourism & Use of assisted death procedures \\
\hline Drug tourism & Traveling to buy/sell narcotic drugs or traveling to use them \\
\hline Poverty tourism & Use of difficult economic situation of societies in less-developed countries for tourist visits \\
\hline Slum tourism & $\begin{array}{l}\text { Use of difficult economic and housing situation of communities inhabiting poor districts in } \\
\text { large agglomerations }\end{array}$ \\
\hline Extreme tourism & Extreme behaviours that are a danger to one's life and health, taking unjustified risks \\
\hline Disaster tourism & $\begin{array}{l}\text { Taking dangerous actions in locations at which a natural or man-made disaster has occurred, } \\
\text { entering areas or structures that are not available to visitors }\end{array}$ \\
\hline Sex tourism & $\begin{array}{l}\text { Sexual relations that are legally forbidden in the tourist's country of origin, taking advantage } \\
\text { of the underage and women in the sex tourism industry }\end{array}$ \\
\hline Party tourism & $\begin{array}{l}\text { Excessive consumption of stimulants and alcohol, often resulting in crossing ethical, cultural } \\
\text { and legal boundaries at the visited location }\end{array}$ \\
\hline Stag/hen party tourism & Consumption of stimulants and alcohol, use of sexual/erotic services at the visited location \\
\hline Thanatotourism & $\begin{array}{l}\text { Excessive commercialisation of sites of death, combining the elements of the sacred and the } \\
\text { profane by the visitors }\end{array}$ \\
\hline Fan tourism & $\begin{array}{l}\text { Brutalisation of support during sporting events, organised fights between supporters, van- } \\
\text { dalism, destruction of property }\end{array}$ \\
\hline
\end{tabular}

Source: own work, based on Stasiak (2015, pp. 53-69). 
It is worth remembering that the search for extreme experiences in tourism often translates into putting one's life or health at risk, or causing damage to the environment and culture.

\section{METHODOLOGY}

The paper focuses on controversies in the Polish tourism market which have not been thoroughly analysed or sufficiently confirmed in academic publications to date. At the same time, the present study may provide valuable information for the tourism industry as it demonstrates directions of change in the tourism market.

The study material was collected using two methods:

- desk research i.e. the analysis of existing materials (so-called virtual ethnography) which allowed for a pre-diagnosis of the supply side of the market focusing on controversial tourism offers;

- Computer Assisted Telephone Interviews (CATI). In the case of travel organisers, phone calls (in addition to mailing) are a natural mode of contact with customers. Additionally, despite its structured character resulting from using an interview questionnaire, a telephone conversation allows the interviewer to provide additional explanations and support in case of difficult or controversial issues or unclear questions. The interviewer reads the questions and notes down the answers using a computer script allowing for automatic scaling of data and creating the required statistical information. The CATI study scenario consisted of seven main questions whose answers were further expanded using conditional (filtering) questions. The average time for a single interview did not exceed four minutes.

Interviews were conducted with representatives of 107 companies operating in the tourism industry. The interviewees included travel organisers $(67 \%)$, travel agencies (20\%), travel intermediaries $(8 \%)$ and other institutions including traveller societies $(5 \%)$.

The study was conducted with the support of a market analysis company and the data used in preparing the paper were part of a larger research project conducted by the author in the years 2016-2019 focusing on controversies in the Polish tourism market.

\section{ANALYSIS OF RESEARCH RESULTS}

The first phase of the analysis involved the evaluation of changes regarding the expectations of customers in relation to the tourism offers that have occurred over the last five years in Poland. The majority of companies studied declared that such changes are noticeable (77\%) and the largest percentage of positive answers was given by agents who act as intermediaries and have various tourism offers in their portfolios. According to members of this group, the expectations of customers are constantly growing and they usually apply to three factors: a higher standard of offer, better price and safety. Other items mentioned include a higher quality of service and new destinations which could become interesting places for tourists to visit.

The aspects mentioned above strongly correspond with the understanding of the notion 'controversial tourism', and this was also discussed with the entrepreneurs. They described 'controversial travel' as that which is related to a lack of safety and dangerous destinations (places where threats related to terrorist activity, conflicts or war are present), sex tourism and extreme tourism. The author listed types of tourism that were closest to controversial forms of travelling and asked the representatives of travel organisers to evaluate them using a scale from 1 to 10 , where 1 denoted 'not controversial at all' and 10 - 'very controversial'.

Respondents identified drug tourism as the most controversial. The second was sex tourism, followed by disaster tourism, medical tourism, slum tourism, fan tourism and poverty tourism, which were classified as moderately controversial. Thanatotourism, extreme travel and hedonistic travel (clubbing, stag/hen parties) were considered slightly controversial (Fig. 1).

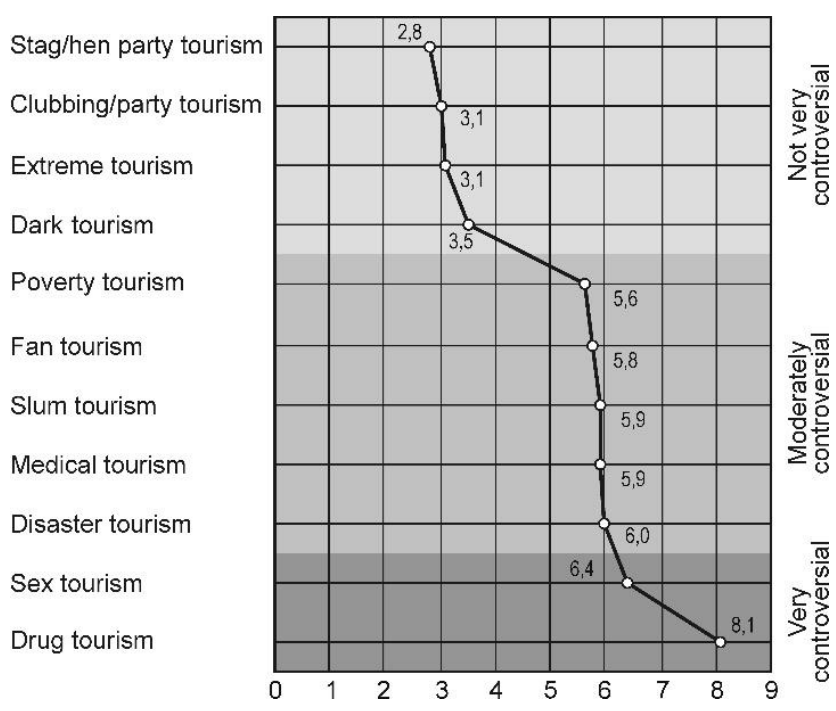

Figure 1. Degrees of controversy of different types of tourism according to the travel organisers interviewed Source: author

To better illustrate the problem, the highest values indicated - 8, 9, 10 - were put together which allowed for precisely establishing the percentage of respondents who selected scores in this range (cumulative percentage) (Fig. 2).

The frequency of inquiries and expectations of customers regarding the offer for controversial forms of travel (on a scale from 1 to 10 , with 1 denoting 'we have never had these' and 10 - 'we have had very often') is different to the 
scores in the previous data set. In this case, the majority of the inquiries (still occasional) apply to party tourism and extreme travel. Less popular are inquiries related to stag/ hen party tourism, thanatotourism and fan tourism (Fig. 3).

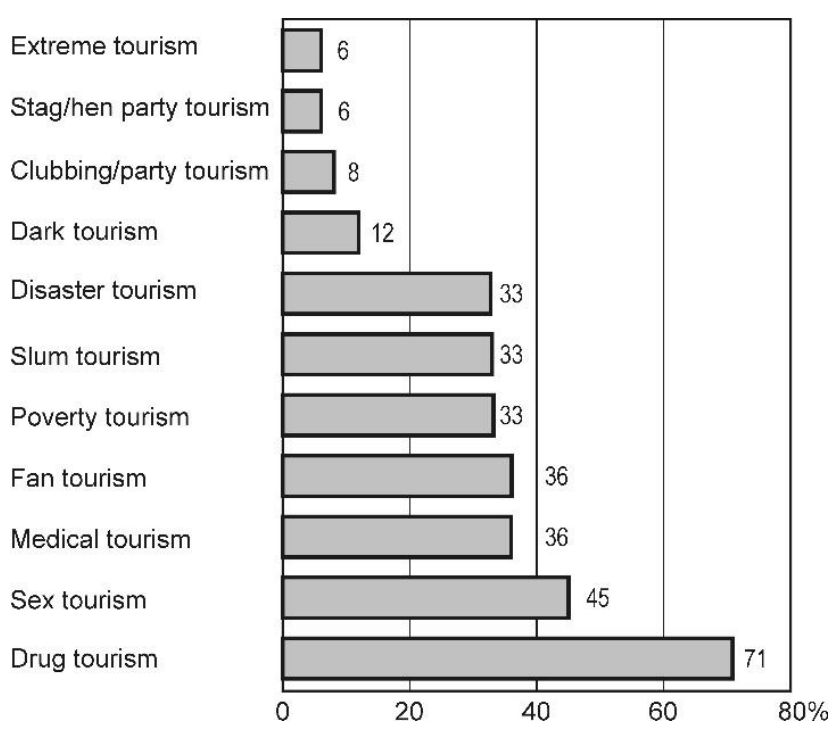

Figure 2. Degree of controversy of different types of tourism: cumulative values of highest scores

Source: author

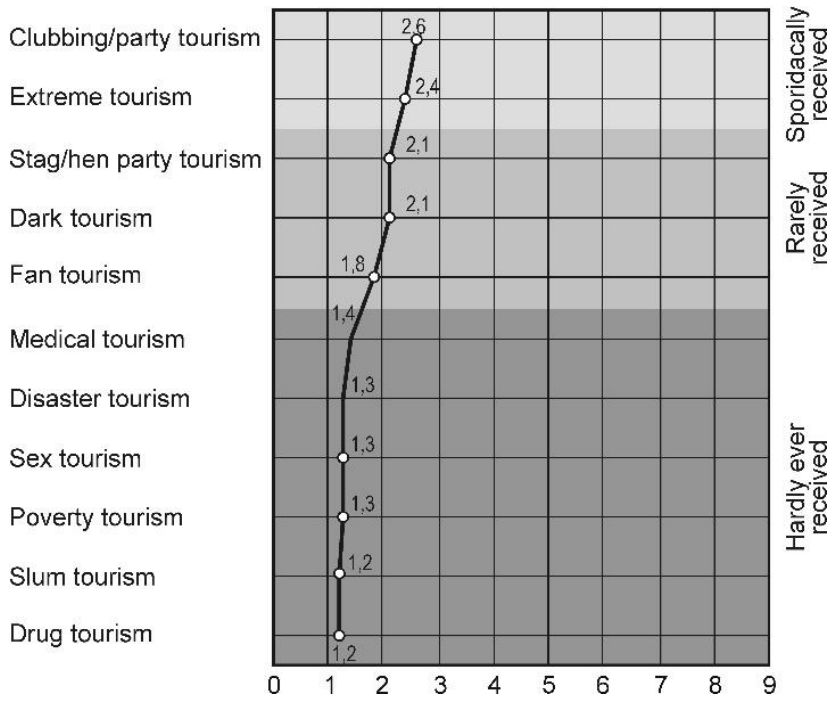

Figure 3. Frequency of customer inquiries related to controversial forms of travel Source: author

According to the respondents, the interest of customers in forms of controversial tourism will increase in the years to come. Almost $75 \%$ of entrepreneurs believe that the travel market will develop in this direction, with tour operators being more convinced of this fact (74\%) than travel agents (57\%) (Fig. 4).

Over half of the respondents (56\%) are of the opinion that the tourism industry in Poland will evolve towards treating controversial forms of tourism as a nor-
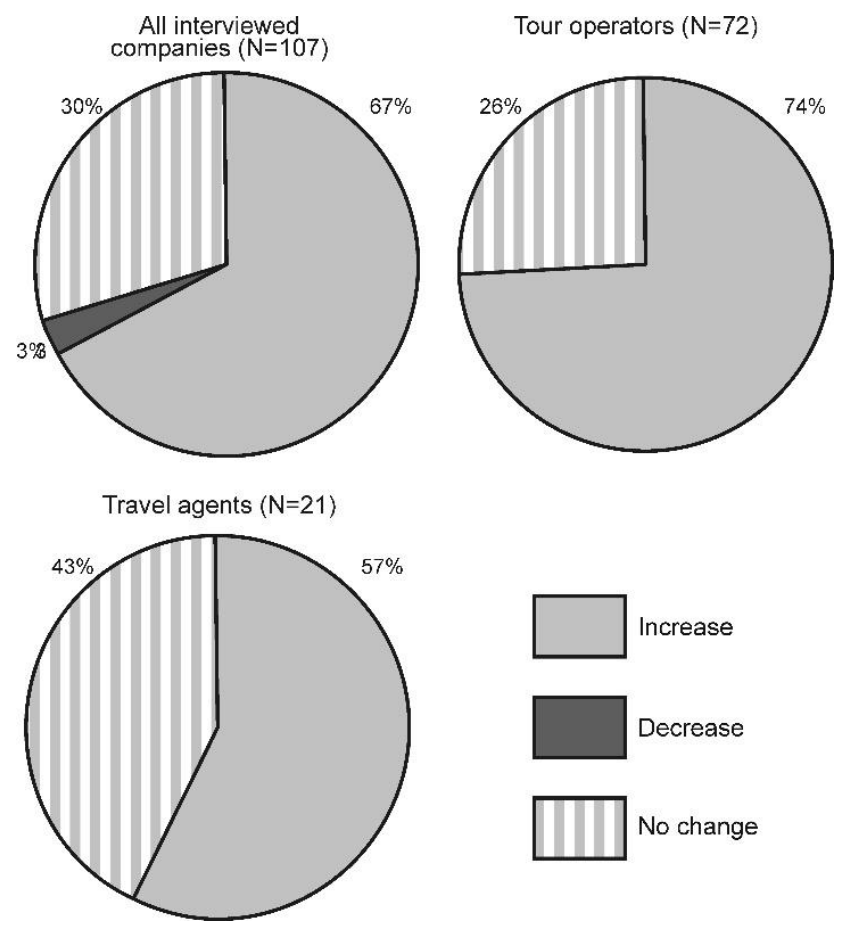

Figure 4. Interest in controversial tourism offers in the future Source: author

mal component of the tourism offer available in the market. An in-depth analysis of the cumulative values demonstrated that $8 \%$ of the respondents answered 'definitely agree', $16 \%$ 'agree' and while $32 \%$ 'somewhat agree'. In total, $32 \%$ of the respondents were of the opposite opinion, with $2 \%$ selecting 'strongly disagree', $8 \%$ 'disagree' and $22 \%$ 'somewhat disagree'.

\section{DISCUSSION}

The results indicate that the representatives of tourism service providers in Poland are aware of controversies related to the tourism industry. They believe that the market has a potential for growth but has yet to develop. The author is aware that an in-depth discussion of the findings is a challenge and it is difficult to find the necessary comparative analyses applicable to the matter in Polish specialist journals. Therefore, the discussion of this problem will not involve comparisons but rather offer a critical look at the phenomenon as a whole.

The fact that there are products on the market that are socially unacceptable but at the same time cheap and easily available, even though their production and distribution is prohibited by Polish law, is a testament to the strength of market mechanisms. The latter also reflect the nature of some forms of tourism (drug tourism, sex tourism, party tourism), especially in the context of products that deprive individuals of freedom and free choice in making purchasing decisions; consumers who are ad- 
dicted to alcohol, sex or drugs. This shows that the market will provide any product, irrespective of its social cost and negative consequences of its use.

Thus, the question arises whether we are able to stop the mechanisms that govern market relations in tourism related to behaviour which the subject literature identifies as deviant. It is impossible to give a precise answer to a question and this has been corroborated in a conversation with a member of the academic community during a meeting organised in the course of the present study:

[...] controversial tourism is growing and it will continue to grow. This is the result of societies getting richer. At the same time, the difference in income between rich and poor countries is growing. [...] in accordance with the well-known cascade effect, controversial tourism (and money) shifts from rich to poor countries.

This economic approach should be supplemented with analyses of the human psyche and the psychological processes which provoke the development of experience tourism in its controversial aspects.

It remains a fact that modern tourists can be seen as those who search, who wish to experience originality and authentic emotions, who want to engage their senses and live through personal experience. The originality of the destination, surprise, extravagance, even activities usually considered shocking often become elements of the everyday lives of travellers. Sometimes the experiences, excitement and psychological satisfaction of a tourist becomes more important than the tourism offer itself. Experiences formed in the visitors' consciousness create a mental space which is not a genuine reflection of real life and can be plastically shaped. According to Stasiak (2011), the resources of a real tourist space have physical limitations and their enhancement may eventually prove impossible. Conversely, it is possible to expand temporal and mental space. Thus, the future of the tourism market may no longer lie in areas whose value stems from their heritage but those which will allow tourists to fill this latter type of space.

\section{CONCLUSIONS}

Research on controversial aspects of the tourist market in Poland is still in its initial stages. Thus, any activities aiming at expanding its scope seem necessary and justified from both economic and social standpoints. Attempts to fill this cognitive gap are often limited by practical problems in conducting thorough studies and obtaining reliable results. This paper is an initial step towards an in-depth analysis of the tourist market, and in terms of its typology (the scope of needs fulfilled by travelling). The emergence of new categories of consumer entails their identification and grouping which has implications for tourism marketing. The creativity of providers in meeting needs will continue to evolve, with the only limiting factors being legal and, in some cases, ethical constraints.

Further studies on controversial tourism may reveal various fields for discussion starting from analyses of the tourism supply sector, through motives and willingness to cater for the needs of this specific market segment, to analyses of consumption processes based on deviant tourist behaviour. These should not only be quantitative studies evaluating its scope but also more in-depth qualitative analyses answering the question why the phenomenon investigated occurs more and more frequently and what drives the purchasing decisions of the customers. Contemporary studies already highlight their behavioural and cognitive scope.

Analyses which focus on the perception of risk when travelling, the safety of visitors, crime and terrorism as well as health aspects and in particular diseases that are a threat to tourists during their travel, are already a strong paradigm in studies on tourism (Baker, Page, Mayer, 2003; Rittichainuwat, Chakraborty, 2009). On the one hand, these factors are deterrents which have a negative impact on tourists' decisions to travel. On the other hand, knowing that such deterrents exist allows for creating preventive solutions. Manipulation of such events may have a positive impact on consumer reactions, including those related to the protection of the environment and culture, and support for areas threatened by disease, as well as sparking curiosity and interest both in the tourism offer and the destination itself.

\section{BIBLIOGRAPHY}

Abrahams, R.D. (1986). Ordinary and extraordinary experience. In: V.W. Turner, E.M. Bruner (eds), The anthropology of experience (pp. 45-72). Chicago: University of Illinois Press.

Arnould, E.J., Price, L.L. (1993). River magic: Extraordinary experiences and the extended service encounter. Journal of Consumer Research, 20, 24-45. DOI: https://doi.org/10.1086/209331

Åstrøm, J.K. (2017). Theme factors that drive the tourist customer experience. International Journal of Culture, Tourism and Hospitality Research, 11, 125-141. DOI: https://doi.org/10.1108/IJCTHR-072015-0070

Baker, M., Page, S., Mayer, D. (2003). Urban visitor perceptions of safety during a special event. Journal of Tourism Research, 41, 355361. DOI: https://doi.org/10.1177/0047287503041004004

Bańko, M. (ed.) (2007). Stownik języka polskiego. Vol. 2. Warszawa: Biblioteka Gazety Wyborczej, Wydawnictwo Naukowe PWN.

Barber, B. (2008). Skonsumowani. Jak rynek psuje dzieci, infantylizuje dorostych i potyka obywateli. Warszawa: Muza.

Bauman, Z. (2007). Konsumenci w społeczeństwie konsumentów. Łódź: Wydawnictwo Uniwersytetu Łódzkiego.

Csíkszentmihályi, M. (1993). The evolving self, a psychology for the third millennium. New York: Harper Collins.

Deighton, J. (1999). The consumption of performance. Journal of Consumer Research, 19, 362-372. DOI: https://doi.org/10.1086/209307 
Ellis, G.D.V. (1994). Measurement and analysis issues with explanation of variance in daily experience using the flow model. Journal of Leisure Research, 26, 337-356. DOI: https:/ / doi.org/10.1080/00222216.1994.11969966

Goodwin, C. (1996). Moving the drama into the factory: The contribution of metaphors to services research. European Journal of Marketing, 30, 13-36. DOI: https://doi.org/10.1108/03090569610130025

Hannabuss, S. (1999). Postmodernism and the heritage experience. Library Management, 20, 295-303. DOI: https:/ / doi.org/$10.1108 / 01435129910276280$

Harris, R., Harris, K., Baron, S. (2003). Theatrical service experiences: Dramatic script development with employees. International Journal of Service Industry Management, 14, 184-199. DOI: https://doi.org/10.1108/09564230310474156

Jasiński, M. (2006). Aspekty monokulturowe gospodarki turystycznej. Zeszyty Naukowe Kolegium Gospodarki Swiatowej SGH, 20, 92-102.

John, J. (1996). A dramaturgical view of the health care service encounter: Cultural value-based impression management guidelines for medical professional behaviour. European Journal of Marketing, 30, 60-74. DOI: https://doi.org/10.1108/03090569610130043

Kacprzak, A., Dziewanowska, K., Skorek, M. (eds) (2015). Gospodarka doświadczeń. Perspektywa polskiego konsumenta. Warszawa: Wydawnictwo Naukowe PWN.

Kopaliński, W. (2014). Stownik wyrazów obcych i zwrotów obcojęzycznych $z$ almanachem. Warszawa: Oficyna Wydawnicza "Rytm".

Lee, B., Shafer, C.S. (2002). The dynamic nature of leisure experience: An application of affect control theory. Journal of Leisure Research, 34, 290-310. DOI: https://doi.org/10.1080/00222216.2002 .11949973

Lubowiecki-Vikuk, A., Paczyńska-Jędrycka, M. (2010). Współczesne tendencje w rozwoju form rekreacyjnych i turystycznych. Poznań: Bogucki Wydawnictwo Naukowe.

MacCannell, D. (1973). Staged authenticity: Arrangements of social space in tourist settings. American Journal of Sociology, 79, 589-603. DOI: https://doi.org/10.1086/225585

MacCannell, D. (1976). The tourist: A new theory of the leisure class. London: MacMillan.

MacCannell, D. (2002). Turysta, nowa teoria klasy próżniaczej. Warszawa: Muza S.A.

Moufakkir, O., Burns, P.M. (2012). Controversies in tourism. Wallingford, OX: CAB International.

Ooi, C.-S. (2002). Cultural tourism and tourism cultures: The business of mediating experiences in Copenhagen and Singapore. Copenhagen: Copenhagen Business School Press.

Ooi, C.-S. (2003). Crafting tourism experiences: Managing the attention product. Retrieved from: https://www.researchgate.net/publication/265987312_Crafting_Tourism_Experiencs_Managing the_Attention_Product (11.09.2018).

Otto, J.E., Ritchie, R.J.B. (1996). The service experience in tourism. Tourism Management, 17, 165-174. DOI: https://doi.org/10.1016/0261-5177(96)00003-9

Panasiuk, A. (2015). Miejsce turystyki kontrowersyjnej w strukturze rynku turystycznego. In: G. Godlewski, M. Zalech (eds), Turystyka kontrowersyjna na wspótczesnym rynku podróży - formy, uwarunkowania, skutki (pp. 7-21). Biała Podlaska: Wydawnictwo AWF.

Pine, B.J., Gilmore, J.H. (1998). Welcome to the experience economy. Retrieved from: https://hbr.org/1998/07/welcome-to-theexperience-economy (10.09.2018).

Podemski, K. (2013). Wyreżyserowana przestrzeń turystyczna. Retrieved from: http://post-turysta.pl/artykul/Wyrezyserowanaprzestrzen-turystyczna (5.09.2018).
Poulsson, S.H.G., Kale, S.H. (2004). The experience economy and commercial experiences. The Marketing Review, 4, 267-277. DOI: https://doi.org/10.1362/1469347042223445

Prentice, R.C., Witt, S.F., Hamer, C. (1998). Tourism as experience: The case of heritage parks. Annals of Tourism Research, 25, 1-24. DOI: https://doi.org/10.1016/S0160-7383(98)00084-X

Rageh, A., Melewar, T.C., Woodside, A. (2013). Using netnography research method to revel the underlying dimensions of the customer/tourist experience. Qualitative Market Research: An International Journal, 16, 126-149. DOI: https://doi.org/10.1108/13522751311317558

Rittichainuwat, B.N., Chakraborty, G. (2009). Perceived travel risks regarding terrorism and disease: The case of Thailand. Tourism Management, 30, 410-418. DOI: https://doi.org/10.1016/j.tourman.2008.08.001

Sigala, M. (2016). Social Media and the co-creation of tourism experiences. In: M. Sotiriadis, D. Gursoy (eds), The handbook of managing and marketing tourism experiences (pp. 85-111). Bradford: Emerald Group Publishing Limited. DOI: https://doi.org/10.1108/978-1-78635-290-320161033

Słownik języka polskiego (2018). Retrieved from: http://sjp.pwn.pl (12.09.2018)

Stamboulis, Y., Skayannis, P. (2003). Innovation strategies and technology for experience - based tourism. Tourism Management, 24, 35-43. DOI: https://doi.org/10.1016/S0261-5177(02)00047-X

Stasiak, A. (2011). Współczesna przestrzeń turystyczna. In: M. Durydiwka, K. Duda-Gromada (eds), Przestrzeń turystyczna. Czynniki, różnorodność, zmiany (pp. 39-51). Warszawa: Wyd. Wydziału Geografii i Studiów Regionalnych, Uniwersytet Warszawski.

Stasiak, A. (2013). New spaces and forms of tourism in experience economy. Turyzm/Tourism, 23 (2), 59-67.

Stasiak, A. (2015). Turystyka kontrowersyjna jako emanacja gospodarki doświadczeń. In: G. Godlewski, M. Zalech (eds), Turystyka kontrowersyjna na wspótczesnym rynku podróży - formy, uwarunkowania, skutki (pp. 53-69). Biała Podlaska: Wydawnictwo AWF.

Urry, J. (1990). The tourist gaze: Leisure and travel in contemporary societies. London: Sage Publications.

Waitt, G. (2000). Consuming heritage: Perceived historical authenticity. Annals of Tourism Research, 27, 835-862. DOI: https://doi.org/10.1016/S0160-7383(99)00115-2

Walker, G. J., Hull, R.B., Roggenbuck, J.W. (1998). On-site optimal experiences and their relationship to off-site benefits. Journal of Leisure Research, 30, 453-471. DOI: https://doi.org/10.1080/00222216.1998.11949843

Waller, J., Lea, S.E.G. (1999). Seeking the real Spain? Authenticity in motivation. Annals of Tourism Research, 26, 110-129. DOI: https://doi.org/10.1016/S0160-7383(98)00058-9

Weisheng, Ch., Ho, K.L. (2017). Let's go cycling: an analysis of tourists' experience on online user-generated content. International Journal of Tourism Cities, 3, 30-42. DOI: https://doi.org/10.1108/IJTC-10-2016-0045

Williams, J.A., Anderson, H.H. (2005). Engaging customers in service creation: A theatre perspective. Journal of Services Marketing, 19, 13-23. DOI: https:// doi.org/10.1108/08876040510579352

Zatori A., Beardsley, M. (2017). On-site and memorable tourist experiences: trending toward value and quality-of-life outcomes. Advances in Hospitality and Leisure, 13, 17-45. DOI: https://doi.org/10.1108/S1745-35422017000

Article received: 22 October 2019 Accepted: 9 August 2019 